\title{
Kontruksi Hukum Perkawinan Beda Agama Dalam Perspektif Hukum Islam Dan Hukum Positif Indonesia
}

\author{
oleh : \\ Dian Septiandani, Dharu Triasih, Dewi Tuti Muryati \\ Fakultas Hukum Universitas Semarang \\ dianseptiandani@gmail.com,dharutriasih@yahoo.com,dewi_tuti@gmail.com
}

\begin{abstract}
Abstrak
Perkawinan beda agama adalah perkawinan antara pria dan wanita yang keduanya memiliki perbedaan agama atau kepercayaan satu sama lain. Perkawinan beda agama bisa terjadi antar sesama WNI yaitu pria WNI dan wanita WNI yang keduanya memiliki perbedaan agama/ kepercayaan juga bisa antar beda kewarganegaraan yaitu pria dan wanita yang salah satunya berkewarganegaraan asing dan juga salah satunya memiliki perbedaan agama atau kepercayaan. Permasalahan pada penelitian ini ialah kajian hukum perkawinan beda agama dalam perspektif hukum Islam dan hukum positif di Indonesia menurut Hukum Islam, UU Perkawinan dan Kompilasi Hukum Islam, pernikahan beda agama tidak diperbolehkan. Peraturan dalam UU Perkawinan sudah sesuai dengan peraturan setiap agama di Indonesia. Keberadaan UU Perkawinan tidak hanya berlaku bagi masyarakat yang beragama Islam saja, namun berlaku bagi semua agama
\end{abstract}

Kata Kunci: Konstruksi Hukum; Perkawina; Beda Agama;

\begin{abstract}
The marriage of different religions is a marriage between men and women who both have different religions or beliefs with each other. Different religious marriages can occur between Indonesian Citizens, WNI men and women who both have differences in religion / beliefs can also be different between citizenship of men and women who one of them foreign citizenship and also one of them has different religions or beliefs. The problem of this study is the study of marriage law of different religions in the perspective of Islamic law and positive law in Indonesia according to Islamic Law, Marriage Law and Compilation of Islamic Law, religious marriage is not allowed. The rules in the Marriage Law are in conformity with the rules of every religion in Indonesia. The existence of Marriage Law applies not only to people who are Moslems but to all religions.
\end{abstract}

Keywords: Legal Construction; Marriage; Different Religion; 


\section{PENDAHULUAN}

\subsection{Latar Belakang}

Perkawinan beda agama hingga kini masih menjadi polemik yang cukup kontroversial dalam masyarakat, khususnya negara yang memiliki berbagai macam penduduk dengan agama yang berbeda-beda seperti Indonesia. Indonesia merupakan negara dengan mayoritas penduduk muslim terbesar dunia, permasalahan-permasalahan menyangkut perkawinan masih sering terjadi, baik permasalahan perkawinan dalam agama Islam, maupun permasalahan perkawinan antar agama.

Melihat aturan dalam Undang-Undang Perkawinan mengenai perkawinan beda agama, menyatakan bahwa perkawinan adalah sah jika dilakukan menurut agama masingmasing pihak, hal ini berarti apabila kemudian perkawinan akan dilakukan oleh pasangan yang berbeda agama, maka harus melihat kepada hukum agama masing-masing pihak memperbolehkan atau tidak mengenai perkawinan beda agama dalam masing-masing ajaran agama tersebut.

Pada tahun 2006 muncul Undang-Undang Nomor 23 Tahun 2006 tentang Administrasi Kependudukan yang telah dirubah dengan Undang-Undang Nomor 24 Tahun 2013tentang Administrasi Kependudukan (UU Adminduk), yang mengatur tentang Pencatatan Perkawinan di Indonesia yaitu dalam Pasal 34, 35 dan 36. Dalam Pasal 35 menyatakan bahwa pencatatan perkawinan sebagaimana dimaksud dalam Pasal 34 berlaku pula bagi perkawinan yang ditetapkan oleh Pengadilan, perkawinan warga negara asing yang dilakukan di Indonesia atas permintaan warga negara asing yang bersangkutan. Sampai dengan Pasal 35 dan 36 dari undang-undang ini tidak ada masalah yang berarti. Namun apabila kita membaca penjelasan atas Pasal 35yang isinya menyatakan bahwa perkawinan yang ditetapkan oleh Pengadilan adalah perkawinan yang dilakukan antar-umat yang berbeda agama.Penjelasan di atas memperlihatkan bahwa suatu penjelasan atas suatu pasaldari suatu undang-undang (Penjelasan Pasal 35 UU Adminduk) mengesampingkan suatu ketentuan atau bunyi dari suatu pasal undang-undang yang lain (Pasal 2 dan 8 UU No 1 Tahun 1974). Meskipun Pasal 8 huruf f Undang-Undang No. 1 Tahun 1974 tidak tegas menyebutkan larangan perkawinan beda agama, namun sudah menjadi pengetahuan umum, bahwa setiap agama di Indonesia melarang perkawinan antara umat berbeda agama. Hal tersebut diperkuat dengan isi Penjelasan atas Pasal 2 ayat (2) Undang-Undang No. 1 Tahun 1974 bahwa tidak 
ada perkawinan diluar hukum masing-masing agamanya dan kepercayaannya itu. Sedangkan isi penjelasan Pasal 35 Undang-Undang No. 23 Tahun 2006 mengizinkan perkawinan beda agama.

Perbedaan pengaturan inilah yang menjadi dasar untuk mengkaji lebih dalam mengenai perkawinan beda agama menurut Hukum Islam, UU Perkawinan, dan Kompilasi Hukum Islam. Agar dapat diketahui bagaimana masing-masing aturan hukum tersebut mengaturnya.

\subsection{Rumusan Masalah}

Penelitan ini berfokus pada bagaimana kajian hukum perkawinan beda agama dalam perspektif hukum Islam, Undang-Undang Perkawinan dan Kompilasi Hukum Islam?

\section{KAJIAN PUSTAKA}

\subsection{Tinjauan Berdasarkan Hukum Islam}

Dilihat dari dua sudut pandang pada hukum perkawinan berbeda agama, perkawinan beda agama, dapat dibedakan menjadi dua berdasarkan pasangan yang menikah, yaitu:seorang laki-laki muslim menikahi perempuan dan seorang muslim perempuan yang menikahi seorang laki-laki yang non muslim, pembagian ini dilakukan karena hukum di antaranya masing-masing berbeda dalam Islam.

Masing-masing sudut pandang tersebut adalah sebagai berikut:

1. Hukum seorang laki-laki muslim menikahi perempuan non muslim (beda agama)

Pernikahan seorang lelaki muslim menikahi seorang yang non muslim dapat diperbolehkan, tapi di sisi lain juga dilarang dalam islam, untuk itu terlebih dahulu sebaiknya kita memahami terlebih dahulu sudut pandang dari non muslim itu sendiri.

a. laki-laki yang menikah dengan perempuan ahli kitab (Agama Samawi), yang dimaksud agama samawi atau ahli kitab disini yaitu orang-orang (non muslim) yang telah diturunkan padanya kitab sebelum $\mathrm{Al}$ quran. Dalam hal ini para ulama sepakat dengan agama Injil dan Taurat, begitu juga dengan nasrani dan yahudi yang sumbernya sama. Untuk hal seperti ini pernikahannya diperbolehkan dalam Islam. Adapun dasar dari penetapan hukum pernikahan ini, yaitu mengacu pada 
Al-Quran, Surat Al Maidah (5):5, isinya: "Pada hari ini dihalalkan bagimu yang baik-baik. Makanan (sembelihan) orang-orang yang diberi Al Kitab itu halal bagimu, dan makanan kamu halal pula bagi mereka. (Dan dihalalkan mengawini) wanita-wanita yang menjaga kehormatan di antara wanita-wanita yang beriman dan wanita-wanita yang menjaga kehormatan di antara orang-orang yang diberi Al Kitab sebelum kamu, bila kamu telah membayar maskawin mereka dengan maksud menikahinya, tidak dengan maksud berzina dan tidak (pula) menjadikannya gundik-gundik. Barang siapa yang kafir sesudah beriman (tidak menerima hukum-hukum Islam) maka hapuslah amalannya dan ia di hari akhirat termasuk orang-orang merugi."

b. Lelaki muslim menikah dengan perempuan bukan ahli kitab. Yang dimaksud dengan non muslim yang bukan ahli kitab disini yaitu kebalikan dari Agama Samawi (langit), yaitu Agama Ardhiy (bumi). Agama Ardhiy (bumi), yaitu agama yang kitabnya bukan diturunkan dari Allah swt, melainkan dibuat di bumi oleh manusia itu sendiri. Untuk kasus yang seperti ini, maka diakatakan haram. Adapun dasar hukumnya yaitu al quran Al Baqarah (2):222, artinya: "Dan janganlah kamu nikahi wanita-wanita musyrik, sebelum mereka beriman. Sesungguhnya wanita budak yang mukmin lebih baik dari wanita musyrik, walaupun dia menarik hatimu. Dan janganlah kamu menikahkan orang-orang musyrik (dengan wanita-wanita mukmin) sebelum mereka beriman. Sesungguhnya budak yang mukmin lebih baik dari orang musyrik walaupun dia menarik hatimu. Mereka mengajak ke neraka, sedang Allah mengajak ke surga dan ampunan dengan izin-Nya. Dan Allah menerangkan ayat-ayat-Nya (perintahperintah-Nya) kepada manusia supaya mereka mengambil pelajaran.”

2. Perempuan muslim menikah dengan laki-laki non muslim. Dari Al-Quran Al Baqarah (2): 221 sudah jelas tertulis bahwa: "...Dan janganlah kamu menikahkan orang-orang musyrik (dengan wanita-wanita mukmin) sebelum mereka beriman...".

Pernikahan seorang muslim perempuan sudah menjadi hal mutlak diharamkan dalam islam, jika seorang perempuan tetap memaksakan diri untuk menikahi lelaki yang 
tidak segama dengannya, maka apapun yang mereka lakukan selama bersama sebagai suami istri dianggap sebagai perbuatan zina. ${ }^{1}$

1.2.Tinjauan Mengenai Perkawinan Beda Agama Berdasarkan Hukum Positif Indonesia

Perkawinan beda agama adalah perkawinan antara pria danwanita yang keduanya memiliki perbedaan agama ataukepercayaan satu sama lain. Perkawinan beda agama bisa terjadiantar sesama WNI yaitu pria WNI dan wanita WNI yang keduanyamemiliki perbedaan agama/ kepercayaan juga bisa antar bedakewarganegaraan yaitu pria dan wanita yang salah satunyaberkewarganegaraan asing dan juga salah satunya memilikiperbedaan agama atau kepercayaan. ${ }^{2}$

Aturan dalam Undang-Undang Perkawinan mengenai perkawinan beda agama, menyatakan bahwa perkawinan adalah sah jika dilakukan menurut agama masing-masing pihak, hal ini berarti apabila kemudian perkawinan akan dilakukan oleh pasangan yang berbeda agama, maka harus melihat kepada hukum agama masing-masing pihak memperbolehkan atau tidak mengenai perkawinan beda agama dalam masing-masing ajaran agama tersebut.

Ketentuan Pasal 35 dalam UU yang menyebut:'Pencatatan perkawinan sebagaimana dimaksud dalam Pasal 34 berlaku pula bagi: a. perkawinan yang ditetapkan oleh Pengadilan.” Penjelasan Pasal 35 huruf a ini menyebutkan, “yang dimaksud dengan 'perkawinan yang ditetapkan oleh pengadilan' adalah perkawinan yang dilakukan antarumat yang berbeda agama." Dengan adanya UU No. 23 Tahun 2006 tentang Administrasi (adminduk) memungkinkan pasangan berbeda agama dicatatkan perkawinannya asal melalui penetapan pengadilan. Selama ini, sebelum keluarnya UU Adminduk, pasangan beda agama biasanya menikah di luar negeri untuk menghindari UU Perkawinan yang melarang pasangan beda agama menikah. Tapi ada juga yang pakai cara penundukan sementara pada salah satu hukum agama, yaitu pagi menikah sesuai agama laki-laki, siangnya menikah sesuai dengan agama perempuan. ${ }^{3}$

\footnotetext{
${ }^{1}$ Islamnya Muslim, "Pernikahan Beda Agama”, (http://www.islamnyamuslim.com/2012/12/hukum-pernikahanbeda-agama-islam-dan.html, diakses 4 April 2017).

${ }^{2}$ Badan Pembinaan Hukum Nasional (BPHN) Kementerian Hukum dan HAM, Pengkajian Hukum tentang Pernikahan Beda Agama, Jakarta, 2011.

${ }^{3}$ Siti Musdah Mulia, dkk, Pernikahan Beda Agama: Kesaksian, Argumen Keagamaan, dan Analisis Kebijakan, (Jakarta: Komnas HAM bekerjasama dengan Indonesian Confrence on Religion and Peace (ICRP)), hlm. 320.
} 


\section{METODE PENELITIAN}

1. Metode Pendekatan

Penelitian ini merupakan "penelitian hukum normatif”.Untuk mengetahui aturan hukum islam dan hukum positif di Indonesia terhadap perkawinan beda agama.

2. Spesifikasi Penelitian

Spesifikasi penelitian ini merupakan penelitian deskriptif analitis, karena bertujuan memberikan gambaran secara menyeluruh, mendalam tentang suatu keadaan atau gejala yang diteliti. ${ }^{4}$

3. Jenis Data

Diperoleh dari studi kepustakaan dan peraturan perundang-undangan, sebagai berikut:

1. Undang-Undang Nomor 1 Tahun 1974 tentang Perkawinan; dengan Peraturan Pemerintah Nomor 9 Tahun 1975 tentang Pelaksanaan UndangUndang Nomor 1 Tahun 1974;

2. Undang-Undang Nomor 24 Tahun 2013 tentang Administrasi Kependudukan;

3. Instruksi Presiden Nomor 1 Tahun 1999 tentang Kompilasi Hukum Islam;

4. Teknik Pengumpulan Data

Data yang ingin diperoleh dalam penelitian ini dikumpulkan dengan cara Studi Dokumen/Kepustakaan.

5. Metode Analisis Data

Data yang diperoleh dalam penelitian disusun secara logis dan sistematis, selanjutnya dianalisis dengan mempergunakan metode analisis kualitatif, dan kemudian disajikan secara kualitatif.

\section{PEMBAHASAN}

\section{Kajian Hukum Perkawinan Beda Agama dalam Perspektif Hukum Islam, UU Perkawinan, dan Kompilasi Hukum Islam}

\footnotetext{
${ }^{4}$ Soerjono Soekanto, Pengantar Penelitian Hukum, Cet. III, UI Press, Jakarta, 1986, hlm. 10.
} 


\subsection{Perspektif Hukum Islam}

Pernikahan umat Islam dengan umat agama lain diperselisihkan para ulama. Pertama, ulama yang mengharamkan, seperti Atha', Ibn Umar, Muhammad Ibn al-Hanfiyah, al-Hadi. Mereka berpatokan pada sejumlah ayat, yaitu: QS. Mumtahanah (60): 10 yang melarang pernikahan umat Islam dengan orang non Islam, juga QS Al Baqarah (2): 221 yang melarang menikahi orang-orang Musyrik. Dua ayat ini, demikian mereka berargumen, telah menghapus kebolehan menikahi orang Ahlul Kitab, sebagaimana dalam Al Maidah (5): $5 .^{5}$

Mengacu pada QS. Mumtahanah tersebut, Umar ibn Khattab menceraikan dua istrinya yang kafir, Binti Abi Umayyah ibn Mughirah dari Bani Makhzum yang kemudian dikawini oleh Mu'awiyah ibn Abi Sufyan, dan Ummu Kultsum binti Amr ibn Jarwal dari Khuza'ah yang kemudian dikawini oleh Abu Jahm ibn Hudzafah ibn Ghanim al-'Adawi. Sikap Umar ini diikuti Thalhah ibn Ubaidillah. Ia menceraikan istrinya yang kafir, Arwa binti Rabiah ibn Al Harits ibn Abdul Muththalib. Alkisah Umar ibn Khattab pernah hendak mencambuk seorang Muslim yang menikahi perempuan Ahli Kitab (yang dahulu meliputi Nasrani dan Yahudi). ${ }^{6}$

Ada ulama yang menghalalkan pernikahan dengan Ahlul Kitab. Ibn Katsir mengutip pernyataan Ibnu Abbas melalui Ali ibn Abi Thalhah, perempuan Ahlul Kitab dikecualikan dari Al Baqarah 221. Pendapat ini didukung Mujahid, Ikrimah, Sa’id ibn Jubair, Makhul, alHasan, al-Dlahhak, Zaid ibn Aslam, dan Rabi ibn Anas. Thabathaba'i berpendirian, pengharaman pada Al Baqarah 221 itu terbatas pada orang watsani (penyembah berhala). ${ }^{7}$

Wanita Islam dilarang kawin dengan laki-laki musyrik (QS Al Baqarah ayat 221) atau dengan laki-laki kafir (QS Mumtahanah ayat 10) atau dengan laki-laki Ahli Kitab (QS Al Maidah ayat 5 dan QS Mumtahanah ayat 10 dan 50). Dari ayat-ayat Al Quran ini dapat disimpulkan bahwa Hukum Islam membolehkan laki-laki yang beragama Islam untuk mengawini wanita Ahli Kitab, namun wanita Muslim tidak diperbolehkan menikah dengan laki-laki yang tidak beragama Islam ataupun Ahli Kitab.

\footnotetext{
${ }^{5}$ Ahmad Nurcholis, Menjawab 101 Masalah Nikah Beda Agama, Banten: Harmoni Mitra Media,2012, hlm. 5.

${ }^{6}$ Al-Thabari, Jami' Al-Bayan, Jilid XII, hlm. 68, dalam Ibid.

${ }^{7}$ Rasyid Ridla, Tafsir Al Quran Al Hakim, Juz VI, hlm. 155, Tafsir Ibn Katsir, juz I, hlm. 296 dan juz II, dan Thabathaba'i, Al Mizan, juz 2, hlm.208, dalam Ibid,. Hlm 5-6.
} 
Perkawinan laki-laki dengan perempuan ahli kitab yang demikian pun baru dapat dilaksanakan apabila mempelai laki-laki yan Islam benar-benar dominan dan tidak tergoda untuk mengikuti agama istrinya dan ia mampu untuk mendidik anak-anaknya menjadi Muslim. Sebaliknya Hukum Islam melarang perkawinan antara wanita yang beragama Islam dengan laki-laki yang bukan Islam disebabkan karena wanita Islam dalam suatu perkawinan berada di bawah kekuasaan suaminya, maka dikhawatirkan wanita Islam itu akan murtad dari Agama Islam dan mengikuti agama suaminya. ${ }^{8}$

\subsection{Perspektif UU Perkawinan}

Pasal 2 UU Perkawinan disebutkan bahwa perkawinan adalah sah, apabila dilakukan menurut hukum masing-masing agamanya dan kepercayaannya itu, kemudian ayat selanjutnya menyebutkan bahwa tiap-tiap perkawinan dicatat menurut peraturan perundangundangan yang berlaku. Pasal ini menyatakan bahwa syarat sah perkawinan adalah dilaksanakan menurut agama dan kepercayaan masing-masing, sebagaimana dalam penjelasan Pasal 2 UU Perkawinan bahwa tidak ada perkawinan di luar hukum masingmasing agama dan kepercayaannya itu, sesuai dengan UUD 1945. Adapun UUD 1945 dalam pasal 29 menyatakan bahwa:

1) Negara berdasarkan Ketuhanan Yang Maha Esa.

2) Negara menjamin kemerdekaan tiap-tiap penduduk untuk memeluk agamanya masingmasing dan untuk beribadah menurut agamanya dan kepercayaannya itu.

Perkawinan dicatat menurut peraturan perundang-undangan yang berlaku.Ketentuan mengenai pencatatan perkawinan diatur lebih lanjut dengan PP No. 9 Tahun 1975 tentang Pelaksanaan UU No. 1 Tahun 1974(PP No. 9/1975).Apabila perkawinan dilakukan oleh orang Islam maka pencatatan dilakukan oleh pegawai pencatat sebagaimana dimaksud dalam UU No. 32 Tahun 1954.Sedangkan, bagi mereka yang melangsungkan perkawinan menurut agama dan kepercayaannya di luar agama Islam, maka pencatatan dilakukan pada Kantor Catatan Sipil (Pasal 2 PP No. 9/1975).

Pada dasarnya, peraturan di Indonesia tidak mengatur secara khusus mengenai perkawinan pasangan beda agama. Dalam hal sahnya perkawinan adalah perkawinan yang

${ }^{8}$ O.S. Eoh,Perkawinan Antar Agama dalam Teori dan Praktek(Jakarta: PT RajaGrafindo Persada, 2001, hlm. 118. 
dilakukan sesuai agama dan kepercayaannya sebagaimana diatur dalam Pasal 2 ayat (1) UUPerkawinan, maka berarti UU Perkawinan menyerahkan pada ajaran dari agama masingmasing.

Namun, permasalahannya apakah agama yang dianut oleh masing-masing pihak tersebut membolehkan untuk dilakukannya perkawinan beda agama. Misalnya, dalam ajaran Islam, seseorang tidak boleh menikah dengan pasangan yang tidak beragama Islam(Al Baqarah [2]: 221). Selain itu, juga dalam ajaran Kristen perkawinan beda agama dilarang (II Korintus 6: 14-18). ${ }^{9}$

\subsection{Perspektif Kompilasi Hukum Islam}

Menurut Kompilasi Hukum Islam Pasal 2 bahwa perkawinan menurut hukum Islam adalah pernikahan, yaitu akad yang sangat kuat atau miitsaaqan gholiidhzan untuk mentaati perintah Allah dan melaksanakannya merupakan ibadah.Kompilasi Hukum Islam Pasal 40 huruf c dan Pasal 44 secara eksplisit mengatur tentang larangan perkawinan antara laki-laki muslim dengan wanita non-muslim dan wanita muslim dengan laki-laki non-muslim. Pasal 40 huruf c Kompilasi Hukum Islam menyatakan sebagai berikut:

Dilarang melangsungkan perkawinan antara seorang pria dengan seorang wanita karena keadaan tertentu;

a. karena wanita yang bersangkutan masih terikat satu perkawinan dengan pria lain;

b. seorang wanita yang masih berada dalam masa iddah dengan pria lain;

c. seorang wanita yang tidak beragama Islam.

Pasal 40 huruf c di atas secara eksplisit melarang terjadinya perkawinan antara laki-laki (muslim) dengan wanita non-muslim (baik Ahl al-Kitab maupun non Ahl al-

\footnotetext{
${ }^{9}$ http://alkitab.sabda.org/passage.php?passage=2Kor\%206:14-18. Isinya sebagai berikut: Janganlah kamu merupakan pasangan ${ }^{\underline{u}}$ yang tidak seimbang dengan orang-orang yang tak percaya ${ }^{1}{ }^{\underline{v}}{ }^{\underline{v}}$ Sebab persamaan apakah terdapat antara kebenaran dan kedurhakaan? Atau bagaimanakah terang dapat bersatu dengan gelap? ${ }^{\underline{w}}$ 6:15 Persamaan apakah yang terdapat antara Kristus dan Belial? ${ }^{\underline{x}}$ Apakah bagian bersama orang-orang percaya ${ }^{\underline{y}}$ dengan orang-orang tak percaya? ${ }^{\underline{z}}$ 6:16 Apakah hubungan bait Allah dengan berhala ${ }^{2}{ }^{\underline{a}}$ Karena kita adalah bait $\underline{\underline{b}}$ dari Allah $\underline{\underline{c}}$ yang hidup menurut firman Allah ini: "Aku akan diam bersama-sama dengan mereka dan hidup di tengah-tengah mereka, dan

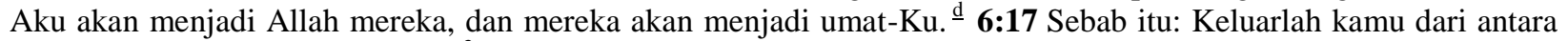
mereka, ${ }^{\mathrm{e}}$ dan pisahkanlah dirimu ${ }^{\underline{3}}$ dari mereka, firman Tuhan, dan janganlah menjamah apa yang najis, maka Aku akan menerima kamu. ${ }^{f}$ 6:18 Dan Aku akan menjadi Bapamu, dan kamu akan menjadi anak-anak-Ku laki-laki dan anak-anak-Ku perempuan ${ }^{\underline{g}}$ demikianlah firman Tuhan, Yang Mahakuasa. ${ }^{\mathrm{h}}$ "
} 
Kitab). Jadi pasal ini memberikan penjelasan bahwa wanita non-muslim apapun agama yang dianutnya tidak boleh dinikahi oleh laki-laki yang beragama Islam.

Sedangkan Pasal 44 menyatakan bahwa seorang wanita Islam dilarang melangsungkan perkawinan dengan seorang pria yang tidak beragama Islam.Pasal ini secara tegas melarang terjadinya perkawinan antara wanita muslim dengan pria nonmuslim baik termasuk kategori Ahl al-Kitab maupun tidak termasuk kategori Ahl alKitab.

Kemudian Pasal 60 Kompilasi Hukum Islam menyatakan sebagai berikut:

1) Pencegahan perkawinan bertujuan untuk menghindari suatu perkawinan yangdilarang hukum Islam dan Peraturan Perundang-Undangan.

2) Pencegahan perkawinan dapat dilakukan bila calon suami atau calon isteri yang akan melangsungkan perkawinan tidak memenuhi syarat-syarat untuk melangsungkan perkawinan menurut hukum Islam dan Peraturan Perundangundangan.

Pasal ini secara tegas memberikan penjelasan tentang pencegahan perkawinan terhadap calon mempelai yang tidak memenuhi syarat yang ditetapkan oleh hukum Islam maupun peraturan perundang-undangan. Pasal ini menguatkan pelarangan perkawinan beda agama.

Dapat disimpulkan bahwa menurut Hukum Islam, UU Perkawinan dan Kompilasi Hukum Islam, pernikahan beda agama tidak diperbolehkan. Peraturan dalam UU Perkawinan sudah sesuai dengan peraturan setiap agama di Indonesia. Keberadaan UU Perkawinan tidak hanya berlaku bagi masyarakat yang beragama Islam saja, namun berlaku bagi semua agama.

V. PENUTUP

5.1 Simpulan

Menurut Hukum Islam, UU Perkawinan dan Kompilasi Hukum Islam, pernikahan beda agama tidak diperbolehkan. Peraturan dalam UU Perkawinan sudah sesuai dengan peraturan setiap agama di Indonesia. Keberadaan UU Perkawinan tidak 
hanya berlaku bagi masyarakat yang beragama Islam saja, namun berlaku bagi semua agama.

5.2 Saran

Adanya aturan hukum yang lebih tegas mengatur perkawinan beda agama, agar hak-hak masyarakat dapat dilindungi, dan tidak ada penyelewengan aturan, baik aturan hukum maupun aturan agama.

\section{DAFTAR PUSTAKA}

$\underline{B U K U}$

Eoh, O.S. Perkawinan Antar Agama dalam Teori dan Praktek. Jakarta: PT RajaGrafindo Persada. 2001.

Mulia, Siti Musdah dkk.Pernikahan Beda Agama: Kesaksian, Argumen Keagamaan, dan Analisis Kebijakan, (Jakarta: Komnas HAM bekerjasama dengan Indonesian Confrence on Religion and Peace (ICRP).

Nurcholis, Ahmad. Menjawab 101 Masalah Nikah Beda Agama. Banten: Harmoni Mitra Media, 2012.

Soekanto, Soerjono. Pengantar Penelitian Hukum. Cet. III, UI Press, Jakarta, 1986.

PERUNDANG-UNDANGAN

Undang-Undang Nomor 1 Tahun 1974 tentang Perkawinan

Undang-Undang Nomor 23 Tahun 2006 jo Undang-Undang Nomor 24 Tahun 2013 tentang Administrasi Kependudukan

Peraturan Pemerintah Nomor 9 Tahun 1975 tentang Pelaksanaan Undang-Undang Nomor 1 Tahun 1974

Instruksi Presiden Nomor 1 Tahun 1999 tentang Kompilasi Hukum Islam WEBSITE 


Islamnya Muslim, $\quad$ "Pernikahan
(http://www.islamnyamuslim.com/2012/12/hukum-pernikahan-beda-agama-
islam-dan.html).

